University of Nebraska - Lincoln

DigitalCommons@University of Nebraska - Lincoln

USDA National Wildlife Research Center - Staff Publications
U.S. Department of Agriculture: Animal and Plant Health Inspection Service

June 2000

\title{
Digestibility, Nitrogen Excretion, and Mean Retention Time by North American Porcupines (Erethizon dorsatum) Consuming Natural Forages
}

\author{
Laura A. Felicetti \\ Washington State University, Pullman, Washington \\ Lisa A. Shipley \\ Washington State University, Pullman, Washington \\ Gary W. Witmer \\ USDA-APHIS-Wildlife Services, gary.w.witmer@usda.gov \\ Charles T. Robbins \\ Washington State University, Pullman, Washington
}

Follow this and additional works at: https://digitalcommons.unl.edu/icwdm_usdanwrc

Part of the Environmental Sciences Commons

\footnotetext{
Felicetti, Laura A.; Shipley, Lisa A.; Witmer, Gary W.; and Robbins, Charles T., "Digestibility, Nitrogen Excretion, and Mean Retention Time by North American Porcupines (Erethizon dorsatum) Consuming Natural Forages" (2000). USDA National Wildlife Research Center - Staff Publications. 671.

https://digitalcommons.unl.edu/icwdm_usdanwrc/671
}

This Article is brought to you for free and open access by the U.S. Department of Agriculture: Animal and Plant Health Inspection Service at DigitalCommons@University of Nebraska - Lincoln. It has been accepted for inclusion in USDA National Wildlife Research Center - Staff Publications by an authorized administrator of DigitalCommons@University of Nebraska - Lincoln. 


\section{Digestibility, Nitrogen Excretion, and Mean Retention Time by North American Porcupines (Erethizon dorsatum) Consuming} Natural Forages

\author{
Laura A. Felicetti ${ }^{1, *}$ \\ Lisa A. Shipley ${ }^{1}$ \\ Gary W. Witmer ${ }^{2}$ \\ Charles T. Robbins ${ }^{3}$ \\ 'Department of Natural Resource Sciences, Washington State \\ University, Pullman, Washington 99164-6410; ${ }^{2}$ USDA, \\ National Wildlife Research Center, Fort Collins, Colorado \\ 80521; ${ }^{3}$ Department of Natural Resource Sciences and \\ Zoology, Washington State University, Pullman, Washington \\ 99164-6410
}

Accepted 6/30/00

\begin{abstract}
North American porcupines (Erethizon dorsatum) subsist predominantly on low-protein, high-fiber, high-tannin diets. Therefore, we measured the porcupine's ability to digest dry matter, fiber, and protein by conducting digestion trials on eight natural forages and one pelleted ration varying in concentration of fiber, nitrogen, and tannins. On these diets, dry matter intake ranged from 5 to $234 \mathrm{~g} / \mathrm{kg}^{0.75} / \mathrm{d}$ and dry matter digestibility ranged from $62 \%$ to $96 \%$. Porcupines digested highly lignified fiber better than many large hindgut fermenters and ruminants. The porcupine's ability to digest fiber may be explained, in part, by their lengthy mean retention time of particles $(38.43 \pm 0.56 \mathrm{~h})$. True nitrogen digestibility was $92 \%$ for nontannin forages and pellets. Endogenous urinary nitrogen was $205 \mathrm{mg} \mathrm{N} / \mathrm{kg}^{0.75} / \mathrm{d}$, and metabolic fecal nitrogen was $2.8 \mathrm{~g} \mathrm{~N} /$ $\mathrm{kg}$ dry matter intake. Porcupines achieved nitrogen balance at relatively low levels of nitrogen intake (346 mg N/ kg $\left.{ }^{0.75} / \mathrm{d}\right)$. Tannins reduced the porcupines' ability to digest protein. However, the reduction in protein digestion was not predictable from the amount of bovine serum albumin precipitated. Like many herbivores, porcupines may ameliorate the effects of certain tannins in natural forages on protein digestibility through physiological and behavioral adaptations.
\end{abstract}

\footnotetext{
"To whom correpondence should be addressed; e-mail: Ifelicet@wsu.edu.
}

Physiological and Biochemical Zoology 73(6):772-780. 2000. (1) 2000 by The University of Chicago. All rights reserved. 1522-2152/2000/7306-0005\$03.00

\section{Introduction}

Herbivores are often challenged in meeting nutritional requirements because many plants contain low levels of nutrients, high levels of fiber, and secondary compounds that may reduce intake and assimilation of nutrients. Therefore, many herbivores have physiological mechanisms that enable them to effectively extract nutrients from plant cell walls and cope with secondary compounds (Batzli and Hume 1994).

The North American porcupine (Erethizon dorsatum), one of North America's largest rodents (5-14 kg), is a generalist herbivore that subsists on diets that contain low levels of nitrogen (e.g., apples, cambium, and conifer needles), high levels of fiber (e.g., mature tree foliage), and high tannin concentrations (e.g., acorns; Roze 1984, 1989; Tenneson and Oring 1985; Black 1992). Porcupines are hindgut fermenters but are not cecatrophic (Björnhag 1987).

Little is known about the porcupine's digestive efficiency and its adaptations for surviving the winter months, when it feeds almost exclusively on tree cambium and conifer needles (Roze 1989). Fournier and Thomas (1997) studied the protein and energy requirements of the porcupine using concentrate diets and suggested that porcupines have physiologically adapted to low-protein diets by reducing protein loss in the feces. Natural forages, unlike concentrates, contain tannins, lignin, and arabinoxylans, which decrease the availability and digestibility of protein (Choct and Anninson 1990; Annison and Choct 1991; Koenig 1991; Schutte et al. 1992; Robbins 1993). Therefore, we extended Fournier and Thomas's (1997) work by conducting a series of trials to determine digestion and mean retention time of natural forages to assess the nutritional ecology of porcupines. Our objectives were to determine (1) dry matter, fiber, and $\mathrm{N}$ digestibility and intake of eight natural forages; (2) minimum N requirements; (3) how tannins affect protein digestibility; and (4) mean retention time (MRT) of liquid and particulate digesta.

\section{Material and Methods}

\section{Experimental Animals}

For our digestion and mean retention time experiments we used five adult porcupines (two males, one female, two un- 
known) that had been wild-caught in Whitman County, Washington. Animals ranged from 8 to $14 \mathrm{~kg}$, and all animals lived in captivity at Washington State University (WSU) in outdoor pens for 1-3 yr before our experiments. When the porcupines were not participating in experiments, they were fed a maintenance diet consisting of a pelleted rodent ration (Harlan Teklab 8604), apples, carrots, and natural browse, with a trace mineral block and water provided ad lib. Maintenance and experimental protocols were approved by WSU's Institutional Animal Use and Care Committee (protocol 2667).

\section{Digestion Trials}

During a series of feeding trials from July 1997 to October 1999, we offered five porcupines each of the following diets: Pacific willow leaves (Salix lasiandra), apples (Macintosh variety; Malus spp.), red oak acorns (Quercus rubra), English oak acorns (Quercus robur), ponderosa pine bark/cambium (Pinus ponderosa), Douglas fir bark/cambium (Pseudotsuga menziesii), lodgepole pine (Pinus contorta) needles, alfalfa (Medicago sativa), and a pelleted rodent ration (Harlan Teklab 8604; Table 1). All natural foods used in this study were selected because they are consumed by free-ranging porcupines (Roze 1984; Black 1992). In addition, we selected alfalfa because it is relatively high in protein and low in tannins. The pelleted ration was used as a comparison to both the natural diets and the earlier work of Fournier and Thomas (1997), which examined porcupines feeding on three pelleted rations. On some of the single-species forage diets, one or more of the animals would refuse to eat enough to participate in the experiments and was eliminated from that trial, resulting in sample sizes for diets ranging from two to five animals (Table 1).

We conducted 5-d-total collection trials following a $10-\mathrm{d}$ pretrial during which animals were moved from their outside facilities to indoor metabolic crates and given time to equilibrate to both the diet and their temporary housing. At the end of each trial, animals were moved back to the outside facility and fed their maintenance diet for at least $15 \mathrm{~d}$. Animals were weighed before and after each 5 -d collection. Mineral blocks were provided, and food and water were offered ad lib. In all but the cambium trials, food was weighed and fed to the porcupines each morning of the trial. To ensure that porcupines ingested homogeneous diets, we prepared all forages before feeding. Willow leaves were stripped from the branches; apples were cut into thirds, omitting the core but leaving the peel; and acorns were shelled. Alfalfa was grown in a greenhouse and harvested to provide a diet of mostly leaves with small stems and no flowers. Orts were collected, weighed and corrected for dry matter, and subtracted from the amount given the previous day to determine how much food each animal ingested.

Feces fell to mesh screens placed below the cages, and urine was funneled to bottles containing ca. $5 \mathrm{~mL}$ of $\mathrm{HCl}$. We dried samples of food, feces, and orts daily at $100^{\circ} \mathrm{C}$ for $24 \mathrm{~h}$ to determine the dry matter content. Samples of food, feces, orts, and urine were collected daily and stored at $-20^{\circ} \mathrm{C}$. At the end of a trial, each individual's orts, feces, and urine were pooled across the 5-d trial. Food, feces, and orts were dried at $50^{\circ} \mathrm{C}$ for $4 \mathrm{~d}$, ground, and stored for later analysis of neutral detergent solubles (NDS), neutral detergent fiber (NDF), acid detergent fiber ( $A D F)$, acid detergent lignin (ADL), N, and energy content. Urine was stored at $-20^{\circ} \mathrm{C}$ and later analyzed for $\mathrm{N}$ content. Additional food samples were freeze-dried, ground, stored in airtight containers with desiccant, and later analyzed for tannin content.

Because porcupines would not eat cambium peeled from the tree, we deviated from the normal feeding and collecting protocol. Porcupines were offered tree rounds $\leq 30 \mathrm{~cm}$ long and $\leq 10 \mathrm{~cm}$ in diameter. Areas eaten from the rounds were traced with pencil and paper and later digitized to determine total area eaten by each animal. Several pieces of bark/cambium from different logs were removed and dried at $100^{\circ} \mathrm{C}$ for $24 \mathrm{~h}$ to determine the dry mass per unit area. This value was used to

Table 1: Composition (100\% dry matter) of natural forages fed to captive North American porcupines

\begin{tabular}{|c|c|c|c|c|c|c|}
\hline Diets & Date & $\begin{array}{l}\text { Nitrogen } \\
\text { Content } \\
(\%)\end{array}$ & $\begin{array}{l}\text { BSA Precipitate } \\
\text { (mg BSA/mg } \\
\text { Dry Forage) }\end{array}$ & $\begin{array}{l}\text { NDF } \\
(\%)\end{array}$ & $\begin{array}{l}\text { ADL } \\
(\%)\end{array}$ & $\begin{array}{l}\text { Energy } \\
\text { Content } \\
(\mathrm{kJ} / \mathrm{g})\end{array}$ \\
\hline Apples .......................... & September 1997 & .41 & .01 & 15.60 & .39 & 16.53 \\
\hline Alfalfa $\ldots \ldots \ldots \ldots \ldots \ldots \ldots \ldots \ldots \ldots \ldots \ldots \ldots \ldots$ & March 1997 & 5.22 & .01 & 31.67 & 3.68 & 18.71 \\
\hline Rodent ration ................... & October 1999 & 4.27 & .00 & 14.30 & 18.30 & 23.02 \\
\hline English oak acorns .............. & October 1997 & .57 & .19 & 23.30 & .80 & 21.93 \\
\hline Red oak acorns .................. & October 1997 & 1.09 & .10 & 16.95 & 1.34 & 21.22 \\
\hline Willow leaves ..................... & August 1997 & 2.70 & .06 & 43.61 & 12.54 & 18.59 \\
\hline Douglas fir cambium ............ & February 1997 & .44 & .13 & 43.20 & 13.37 & 22.52 \\
\hline Ponderosa pine cambium ....... & February 1997 & .56 & .11 & 60.20 & 22.72 & 26.41 \\
\hline Lodgepole pine needles .......... & April 1999 & 1.13 & .12 & 47.30 & 14.30 & 19.09 \\
\hline
\end{tabular}

Note. Neutral detergent fiber $=\mathrm{NDF}$, acid detergent lignin $=\mathrm{ADL}$, and bovine serum albumin $=\mathrm{BSA}$. 
convert area to dry mass ingested. Pieces of bark and cambium that fell through to the mesh screens were considered orts; bark and cambium left on the log were not. Orts were also dried at $100^{\circ} \mathrm{C}$ for $24 \mathrm{~h}$. We subtracted the dry mass of the orts from the initial mass of the areas eaten to calculate dry matter ingested by each animal. The collection of food, feces, and urine for lab analysis did not deviate from the previous protocol.

We measured the gross energy of the food, feces, and urine using bomb calorimetry. Foods and feces were analyzed for fiber composition using sequential detergent analysis (Goering and Van Soest 1970) with filter bags, sodium sulfite, and alpha amylase (Ankom Fiber Analyzer ${ }^{200 / 220}$, Ankom Technology, Fairport, N.Y.). Nitrogen content was determined with Kjeldahl analysis. Tannin binding capacity of forages was determined by the bovine serum albumin (BSA) method (Robbins et al. $1987 a$ ). Forages that precipitated $\leq 0.01 \mathrm{mg}$ BSA per milligram dry forage (i.e., apples, alfalfa, pellets) were considered nontannin diets (Table 1). All other forages were considered tannincontaining diets.

Metabolic fecal N (MFN, g N/100 g feed) was estimated as the negative $y$-intercept of the regression of digestible $\mathrm{N}$ ( $\mathrm{g} \mathrm{N} / 100 \mathrm{~g}$ food) against dietary $\mathrm{N}(\%)$, with true $\mathrm{N}(\%)$ as the slope of the line. The $y$-intercept of the regression of urinary $\mathrm{N}\left(\mathrm{mg} \mathrm{N} / \mathrm{kg}^{0.75} / \mathrm{d}\right)$ against dietary $\mathrm{N}$ intake (mg N/ $\mathrm{kg}^{0.75} / \mathrm{d}$ ) provided an estimate of endogenous urinary $\mathrm{N}$ (EUN, mg N/ $/ \mathrm{kg}^{0.75} / \mathrm{d}$ ). Minimum $\mathrm{N}$ requirements of porcupines (i.e., the amount of $\mathrm{N}$ an animal must ingest to counteract the minimum constant losses from feces and urine, $\mathrm{mg} \mathrm{N} / \mathrm{kg}^{0.75} / \mathrm{d}$ ) was estimated as the $x$-intercept of the regression of $\mathrm{N}$ balance ( $\mathrm{N}$ ingested $-\mathrm{N}$ excreted, mg N/ $\mathrm{kg}^{0.75} / \mathrm{d}$ ) against dietary $\mathrm{N}$ intake $\left(\mathrm{mg} \mathrm{N} / \mathrm{kg}^{0.75} / \mathrm{d}\right)$. We calculated necessary dietary protein content (\%) from the equation $\{[\mathrm{EUN}+\mathrm{MFN}(\mathrm{DMI}) \times 6.25] / \mathrm{DMI} / 0.74\} \times 100$ (Robbins 1993).

Tannin diets were omitted from these analyses because tannins artificially increase fecal $\mathrm{N}$ losses and decrease urinary losses (Robbins et al. 1987a). Because we used only three nontannin diets in our experiments (apples, alfalfa, Teklab pellets), we strengthened our assessment of MFN, EUN, and the minimum $\mathrm{N}$ requirements of porcupines by including data from Fournier and Thomas (1997), who conducted similar experiments with porcupines consuming three pelleted nontannin rations ranging from $0.8 \%$ to $4.6 \% \mathrm{~N}$. Animals that lost $>5 \%$ of their body mass during the trials were omitted from this analysis because when animals lose mass they may be metabolizing protein, which would influence MFN and EUN.

To examine the effects of condensed tannins on protein digestion, we calculated the residuals of all tannin and nontannin forages from the best-fit line of digestible $\mathrm{N}$ ( $\mathrm{g} \mathrm{N} / 100 \mathrm{~g}$ feed) against dietary $\mathrm{N}(\%)$. We then conducted a linear regression (SAS Institute 1985) of the residuals against a measure of the protein-precipitating capacity of the tannins in the forages (i.e., BSA precipitation, $\mathrm{mg} / \mathrm{mg}$ forage dry matter; Robbins et al. 1987a). In addition, we assessed whether BSA precipitation of forages contributed to predicting protein and fiber digestibility by using a partial $F$ statistic from multiple regressions of NDF digestibility as a function of ADL content of the forage cell wall and BSA precipitation, NDS digestibility as a function of NDS content of the food and BSA precipitation, and nitrogen digestibility as a function of N content of the food and BSA precipitation.

\section{Mean Retention Time Trial}

We conducted a separate experiment to determine the mean retention time (MRT) of liquid and particle digesta within the whole digestive tract of three of the porcupines consuming Pacific willow leaves (representing a relatively fibrous, tannincontaining natural forage), using cobalt-ethylenediamine tetraacetic acid (Co-EDTA) to mark liquid digesta and yterrbium nitrate $\left(\mathrm{YbNO}_{3}\right)$ to mark particulate digesta. Preparation of the Co-EDTA complex followed procedures outlined by Uden et al. (1980). Because directly administering the solution to the animals was difficult, the inert Co-EDTA was absorbed in small pieces of apple that were subsequently consumed by all animals in a pulse dose.

To mark the food particles, a $\mathrm{YbNO}_{3}$ solution was prepared by dissolving $4 \mathrm{~g}$ in $100 \mathrm{~mL}$ of distilled water. Dried samples of willow (one leaf per animal, air-dried for $24 \mathrm{~h}$ ) were soaked in the solution for approximately $5 \mathrm{~h}$, washed with distilled water, and presented to the animals in a pulse dose (Feng et al. 1995). Labeling particulate forages by immersing them in $\mathrm{Yb}$ allows labeled particles to have a similar flow rate to that of unlabeled particles (Mader et al. 1984).

Animals were fed only fresh willow leaves ad lib. for $5 \mathrm{~d}$ before and during the 108-h trial period. Feces were collected at $\leq 4$-h intervals unless intervals between defecations occurred less frequently. In such cases, feces were collected opportunistically as often as possible. Feces were frozen at $-20^{\circ} \mathrm{C}$ and were later dried at $100^{\circ} \mathrm{C}$ and ground. Ground samples were analyzed for $\mathrm{Co}$ and $\mathrm{Yb}$ concentrations by neutron activation (Gray and Vogt 1974).

MRT of both markers were calculated by fitting the following equation (Brandt and Thacker 1958; Sakaguchi et al. 1987),

$$
Y=Y_{0} \times \mathrm{e}^{-k t},
$$

to the downward portion of the marker concentration curve, where $Y$ represents the marker concentration in the feces at time $t, Y_{0}$ is constant, $k$ is the rate constant, and $t$ is the time interval after feeding of the markers. MRT equaled the sum of the reciprocal of $k$ and the transit time (TT), which is the initial appearance of the marker after dosing (Sakaguchi et al. 1987). MRT was compared between liquid and particulate digesta with a paired $t$-test $(\dot{\alpha}=0.05)$. 


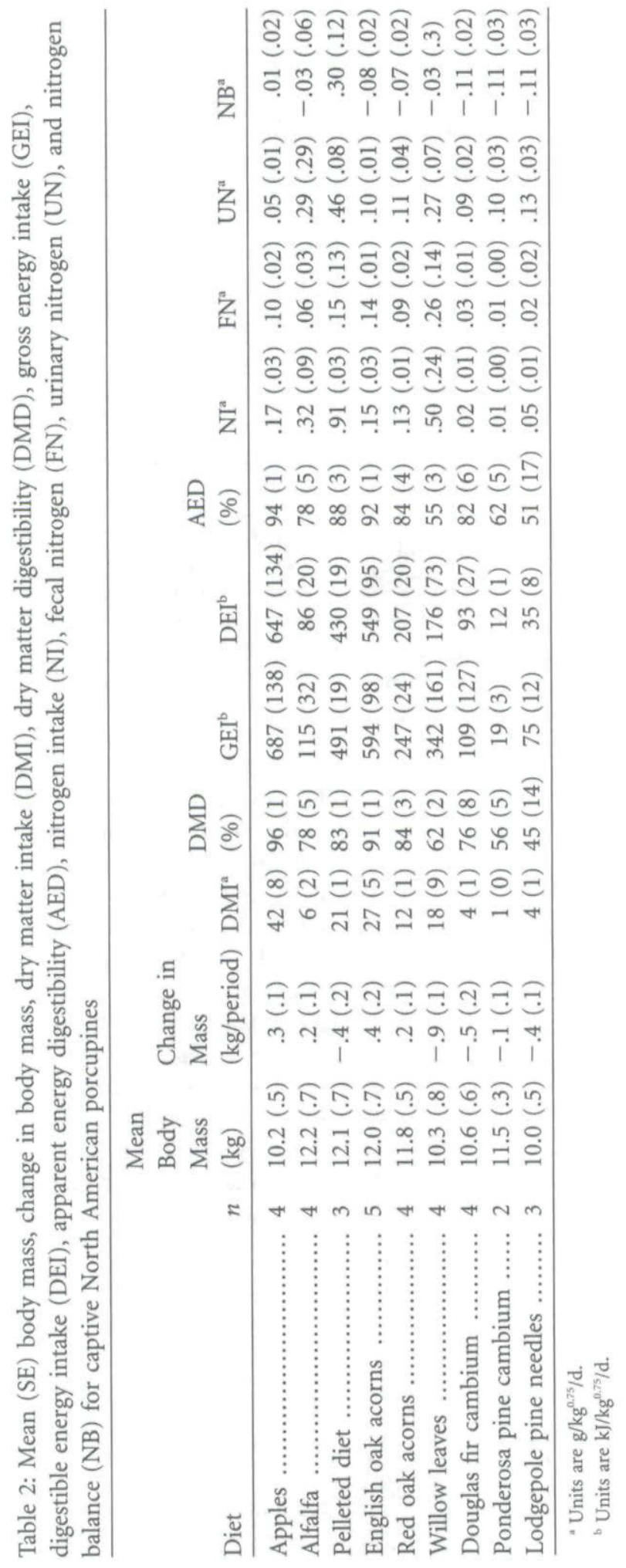




\section{Results}

\section{Intake and Digestibility of Dry Matter and Energy}

Digestible dry matter and digestible energy intake ranged from $1 \mathrm{~g} / \mathrm{kg}^{0.75} / \mathrm{d}$ and $12 \mathrm{~kJ} / \mathrm{kg}^{0.75} / \mathrm{d}$ on the ponderosa pine cambium trial to $42 \mathrm{~g} / \mathrm{kg}^{0.75} / \mathrm{d}$ and $647 \mathrm{~kJ} / \mathrm{kg}^{0.75} / \mathrm{d}$ on the apple trial (Table 2 ). Animals maintained their body mass on the apples, English oak acorns, red oak acorns, alfalfa, and pine cambium, which suggests animals were in energy and nutrient balance on these diets (Table 2).

NDF digestibility ranged from a low of $46.6 \%$ for the lodgepole pine needle diet to a high of $96.5 \%$ for the apple diet. The ability of porcupines to digest NDF was a predictable function of the ADL content of NDF $(F=6.328, P<0.0173$; Fig. 1). Porcupines had a high NDF digestibility relative to the ADL content when compared to other hindgut fermenters and many ruminants (Fig. 1; Robbins 1993, p. 295). Tannin diets did not have a consistently lower NDF or NDS digestibility (Fig. 1), and BSA precipitation did not significantly contribute to predicting NDF digestibility after controlling for ADL of NDF content $(F=1.22, P=0.28)$, nor did it contribute to predicting NDS digestibility after controlling for NDS content $(F=0.11, P=74)$.

\section{Intake and Digestibility of Nitrogen}

Apparent digestible $\mathrm{N}$ was significantly correlated with dietary $\mathrm{N}$ content of nontannin diets $(F=14.47, P=0.0006$; Table 2 ; Fig. 2). MFN was $2.8 \mathrm{~g} \mathrm{~N} / \mathrm{kg}$ dry matter, and true $\mathrm{N}$ digestibility

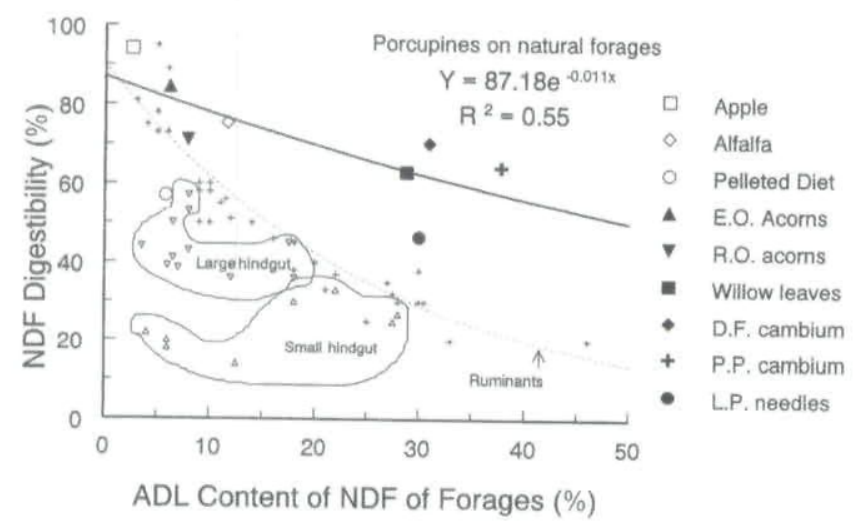

Figure 1. Mean neutral detergent fiber (NDF) digestibility of eight natural forages consumed by captive North American porcupines as a function of the acid detergent lignin (ADL) content of NDF of those forages. Values for porcupines eating a pelleted rodent ration (circles) and for ruminants (plus symbols), large (down triangles) and small (up triangles) eutherian hindgut fermenters, feeding on natural forages (Robbins 1993) are provided for comparison. (E.O. = English oak, R.O. $=$ red oak, D.F. $=$ Douglas fir, P.P. $=$ ponderosa pine, and L.P. = lodgepole pine).

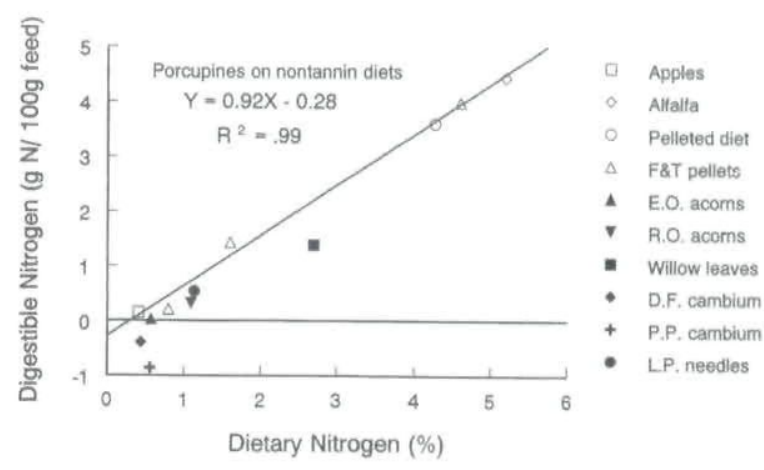

Figure 2. Mean apparent digestible nitrogen of captive North American porcupines as a function of dietary nitrogen of two nontannin forages (apples and alfalfa) and four nontannin pelleted diets, including our pelleted ration (open circles) and three pelleted diets ranging from $0.8 \%$ to $4.6 \%$ (open, up triangles) from Fournier and Thomas (1997). Metabolic fecal nitrogen is the $y$-intercept. Tannin-containing forages ( filled symbols, E.O. = English oak, R.O. = red oak, D.F. = Douglas fir, $P . P .=$ ponderosa pine, and L.P. $=$ lodgepole pine) are provided for comparison.

was $92 \%$. Digestibility for all tannin-containing diets fell below the regression between dietary protein and digestible protein for nontannin diets (Fig. 2). When accounting for $\mathrm{N}$ content of the diet, BSA precipitation of the forage did not significantly contribute to the prediction of digestible $\mathrm{N}(F=3.65, P=$ 0.07 ), and the slope of the relationship between digestible protein reduction and BSA was not significant $(F=2.53, P=$ $0.15, R^{2}=0.26$; Fig. 3).

Urinary $\mathrm{N}$ excretion increased with $\mathrm{N}$ intake $(F=69.64$, $P<0.0001$; Table 2; Fig. 4). EUN was $205 \mathrm{mg} / \mathrm{kg}^{0.75} / \mathrm{d}$. Nitrogen balance was positively related to total nitrogen intake ( $F=$ $51.45, P<0.0001)$. Apples and rodent chow were the only diets in which porcupines achieved a positive $\mathrm{N}$ balance (Table 2). Porcupines required a minimum $\mathrm{N}$ intake of $346 \mathrm{mg} \mathrm{N} / \mathrm{kg}^{0.75}$ / $\mathrm{d}$ when eating nontannin diets (Fig. 5). At high levels of DMI and low levels of dietary protein, porcupines have a protein requirement comparable with other herbivores; however, if DMI is relatively low, porcupines may need to consume forages with higher protein concentrations (Fig. 6).

\section{Mean Retention Time}

Porcupines retained liquid digesta $(\bar{X}=57.42 \mathrm{~h}, \mathrm{SE}=2.54 \mathrm{~h}$, $n=3)$ longer than particulate digesta $(\bar{X}=38.43 \mathrm{~h}, \mathrm{SE}=$ $0.56 \mathrm{~h}, n=3, t=4.24, P=0.05)$. Confidence intervals for liquid $( \pm 7.3)$ and particulate $( \pm 1.64)$ MRT did not overlap. Although estimated MRT was similar among individuals, marker excretion did not decline smoothly but spiked several times (Fig. $7 a-7 c$ ). 


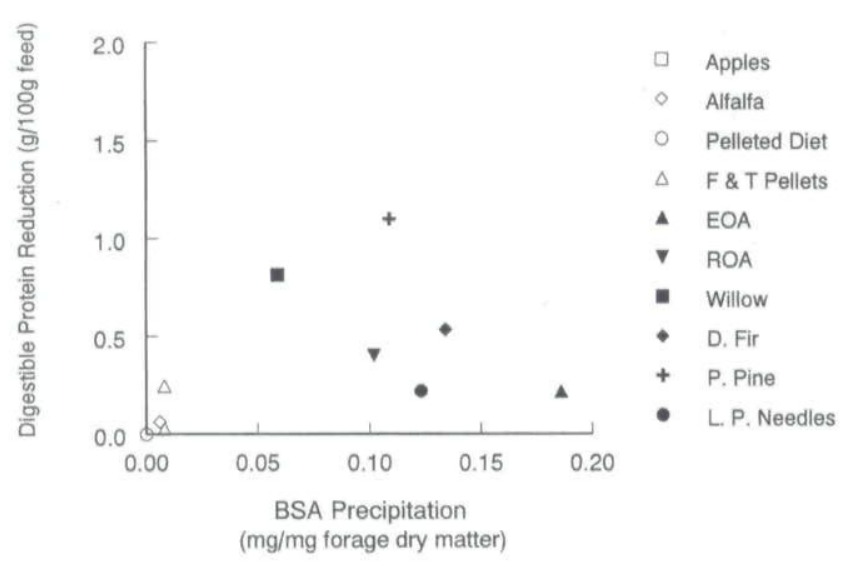

Figure 3. The mean reduction in digestible protein caused by the ability of dietary tannins to precipitate of bovine serum albumin (BSA) in tannin diets (closed symbols) and nontannin diets (open symbols) fed to captive North American porcupines $(E O A=$ English oak acorns, $R O A=$ red oak acorns, $D$. Fir $=$ Douglas fir, $P$. Pine $=$ ponderosa pine, and $L . P .=$ lodgepole pine). Three nontannin pelleted diets ranging from $0.8 \%$ to $4.6 \%$ (open, up triangles) from Fournier and Thomas (1997) are included for comparison.

\section{Discussion}

Although fiber digestibility is expected to be greater in larger animals and in ruminant herbivores than in hindgut fermenters (Parra 1978; Alexander 1993), porcupines in our experiments digested fiber more efficiently than many large hindgut fermenters and ruminants on a range of lignified forages (Fig. 1; Robbins 1993, p. 295). For example, when feeding on willow leaves $(44 \% \mathrm{NDF})$, porcupines had a higher NDF digestibility $(\bar{X}=69 \%, \mathrm{SE}=1 \%)$ than the blue duiker $(\bar{X}=51 \%, \mathrm{SE}=$ $1 \%$; Wenninger and Shipley 2000), a small ruminant (Cephalophus monticola), and domestic rabbits $(\bar{X}=59 \%, \mathrm{SE}=2 \%$; L. A. Shipley, unpublished data) feeding on the same diet.

Several mechanisms may help explain the porcupine's ability to digest fiber. First, porcupines have a relatively large cecum and a colonic separation mechanism, which supplies $16 \%$ of their basal metabolic energy requirements (Johnson and McBee 1967), and a distal colon four times longer than that of similarly sized beavers (Castor canadensis; Vispo and Hume 1995). We found that porcupines retain particles within their gastrointestinal tract longer than expected for a hindgut fermenter of their size, allowing more time for microbial and mechanical breakdown of plant fiber (Hume 1982). On the basis of interspecific relationships for hindgut fermenters (Robbins 1993, p. $329)$, an 11-kg hindgut fermenter is expected to retain food particles for $21 \mathrm{~h}$ and liquids for $28 \mathrm{~h}$, whereas our porcupines retained particulate and liquid digesta nearly twice as long (Fig. 7), which exceeds even the time predicted for an $11-\mathrm{kg}$ ruminant (33 h; Robbins 1993, p. 327).

MRT is affected by many properties of forages consumed, including fiber content, specific gravity of particles, particle size, and intake (Cork 1994; Conklin-Brittain and Dierenfeld 1996; Wenninger and Shipley 2000). In our experiments, low DMI by porcupines may have increased MRT; however, Roze (1989) also reported a long MRT ( $48 \mathrm{~h})$ for porcupines eating apples. Blue duikers consuming willow leaves under the same experimental protocol retained particles for only $17 \mathrm{~h}$ and liquid digesta for $19 \mathrm{~h}$, but when they were fed figs (Ficus carica) and fresh alfalfa, particle MRT increased to $35-40 \mathrm{~h}$ and liquid to $26 \mathrm{~h}$ (Wenninger and Shipley 2000). Therefore, the MRT estimated for porcupines on willow leaves may represent a minimum MRT and may be longer on other diets. Also, when particles are labeled with $\mathrm{YbNO}_{3}, \mathrm{MRT}$ may appear shorter than when they are chromium mordanted (Mader et al. 1984; Wenninger and Shipley 2000). Like most hindgut fermenters (Hume 1982), porcupines retained the liquid portion of their digesta longer than the particles. Uneven excretion of both liquid and particulate markers may have been caused by different digestive pools created by the porcupine's colonic separation mechanism. Furthermore, long $(8-10-\mathrm{h})$ periods between defecations may have affected the concentration of marker in an individual sample.

Second, thorough mastication of food may also contribute to the porcupine's ability to digest fiber. Small animals can masticate food into fine particles, thereby maximally exposing fiber for fermentation (Conklin and Dierenfeld 1994). In addition, porcupines may contain anaerobic fungi in their cecum that facilitate cell wall degradation (Van Soest 1982; Oprin and Joblin 1988; Theodorou et al. 1988).

Change in body mass was not correlated with DMI, DEI, and $\mathrm{N}$ balance. Despite a relatively low DMI, porcupines maintained a relatively constant body mass during all digestion trials except on the willow leaves and Douglas fir cambium diets.

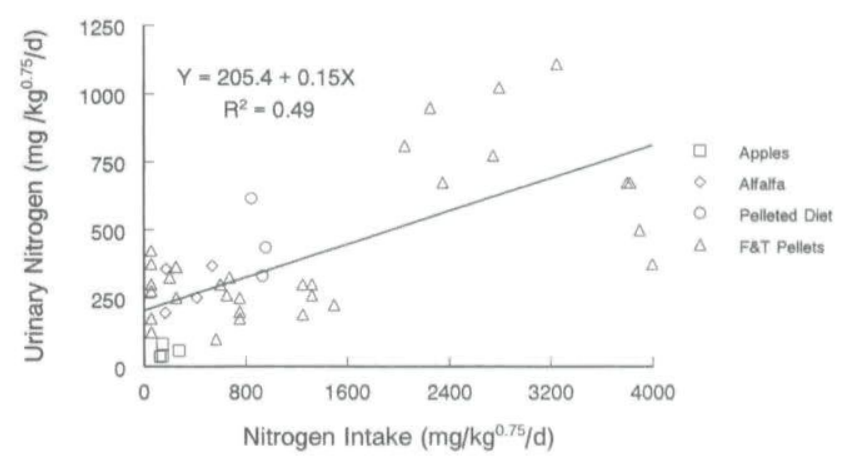

Figure 4. Urinary nitrogen as a function of nitrogen intake of two to five individual North American porcupines consuming two nontannin forages (apples and alfalfa) and four nontannin pelleted diets, including our pelleted ration (circles) and three pelleted diets ranging from $0.8 \%$ to $4.6 \%$ (up triangles ) from Fournier and Thomas (1997). Endogenous urinary nitrogen is the $y$-intercept. 


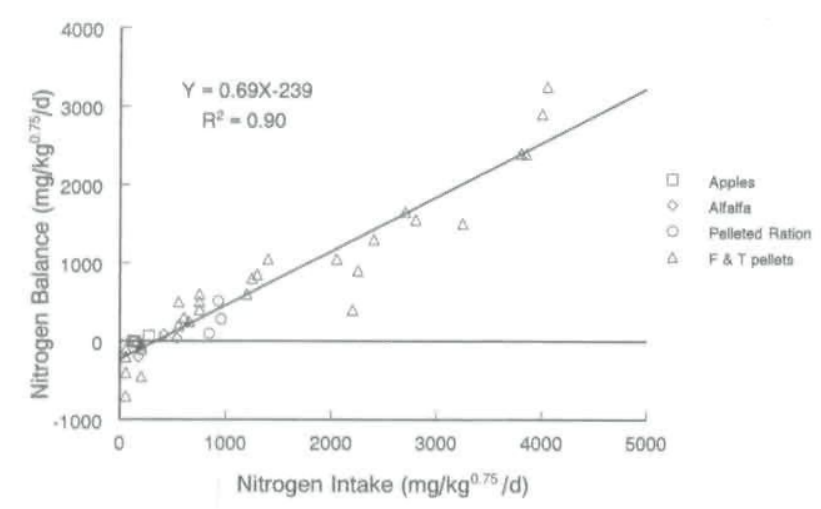

Figure 5. Nitrogen balance as a function of total nitrogen intake of two to five individual North American porcupines consuming two nontannin forages (apples and alfalfa) and four nontannin pelleted diets, including our pelleted ration (circles) and three pelleted diets ranging from $0.8 \%$ to $4.6 \%$ (up triangles) from Fournier and Thomas (1997). Minimum nitrogen requirements are found at the $x$-intercept.

Measurement of body mass before and after trials may have been affected by changes in energy expenditure of porcupines. Porcupines appeared more agitated during the trials in which they either lost mass or maintained mass but ingested relatively high amounts of digestible energy (e.g., apple and willow trials). In addition, animals may have lost or gained either lean tissue or fat; therefore, it is difficult to relate mass change to the amount of energy and protein ingested. During the trials on which porcupines ate relatively little but maintained their mass or lost relatively little mass, the porcupines appeared lethargic (e.g., ponderosa pine cambium, Douglas fir cambium, and lodgepole pine needles). In addition, mass changes over a 5-d period may have been confounded with variation in gut fill and water intake.

Porcupines seem well adapted physiologically to subsist on low-protein foods that dominate their winter diets. MFN excretion for porcupines ( $2.8 \mathrm{~g} \mathrm{~N} / \mathrm{kg}$ dry matter intake) was on the low end of the normal range of $1-9 \mathrm{~g} \mathrm{~N} / \mathrm{kg}$ DMI (Robbins 1993; Fig. 2) and was comparable to the leaf- and forage-eating marsupial mean of $4.2 \pm 1.4 \mathrm{~g} \mathrm{~N} / \mathrm{kg}$ DMI (Robbins 1993). In contrast, the EUN of porcupines ( $205 \mathrm{mg} / \mathrm{kg}^{0.75} / \mathrm{d}$; Fig. 5) was slightly higher than the nonruminant eutherian mean (160 \pm $22 \mathrm{mg} / \mathrm{kg}^{0.75} / \mathrm{d}$ ) and much higher than both the ruminant mean of $93 \pm 40 \mathrm{mg} / \mathrm{kg}^{0.75} / \mathrm{d}$ and the marsupial mean of $53 \pm 28 \mathrm{mg} /$ $\mathrm{kg}^{0.75} / \mathrm{d}$ (Robbins 1993). However, MFN is the major determinant of $\mathrm{N}$ requirements at higher levels of DMI because it is a larger source of $\mathrm{N}$ loss than EUN; therefore, the overall $\mathrm{N}$ requirement of porcupines $\left(346 \mathrm{mg} \mathrm{N} / \mathrm{kg}^{0.75} / \mathrm{d}\right.$ ) was lower than the mean for other eutherian herbivores $\left(582 \pm 235 \mathrm{mg} / \mathrm{kg}^{0.75}\right.$ ) d; Robbins 1993).

Although both our study and that of Fournier and Thomas (1997) showed that porcupines can achieve $\mathrm{N}$ balance at low levels of N intake, porcupines in Fournier and Thomas's (1997) study failed to reach $\mathrm{N}$ balance on a low-protein $(5 \%)$ diet. They thus suggested that porcupines are unable to detect $\mathrm{N}$ deficiencies and adjust food intake accordingly. However, our porcupines reached $\mathrm{N}$ balance on apples, which contained $<3 \%$ crude protein. Therefore, our observations suggest that porcupines may be able to detect $\mathrm{N}$ deficiencies.

Although tannins clearly reduced protein digestibility of some forages, BSA assays did not provide a good measure of this reduction. In contrast, Robbins et al. $(1987 a, 1987 b)$ found that the amount of BSA precipitation predicted $90 \%$ of the reduction of protein digestibility by mule deer and white-tailed deer (Odocoileus virginianus). The unpredictable relationship between BSA precipitation and digestible protein reduction could have been caused by highly specific salivary binding proteins or the breakdown of some tannin-protein complexes. For example, moose (Alces alces) and beavers excrete salivary binding proteins specific for linear condensed tannins found in their preferred foods (Hagerman and Robbins 1992).

Another mechanism animals have developed to decrease the effects of tannins is a specialized ceca with specific cecal microbes that have been hypothesized to dissociate the tanninprotein complex in some arboreal marsupials (McArthur and Sanson 1991). Therefore, arboreal marsupials, and possibly porcupines, may actually absorb some of the tannin-protein complexes and excrete the tannin metabolites in the urine (McArthur and Sanson 1991).

Some animals do not possess a known mechanism to overcome the effect of tannins on protein digestion (Fleck and Tomback 1996). These animals may need to ingest excess amounts of protein to saturate the tannins and provide additional protein for nutritional needs (Fleck and Tomback 1996).

Although free-ranging porcupines seek high-energy fruit and nut diets seasonally and seem to avoid forages with higher tannin and monoterpene levels (Roze 1989; Snyder and Linhart 1997), our study showed that porcupines are physiologically

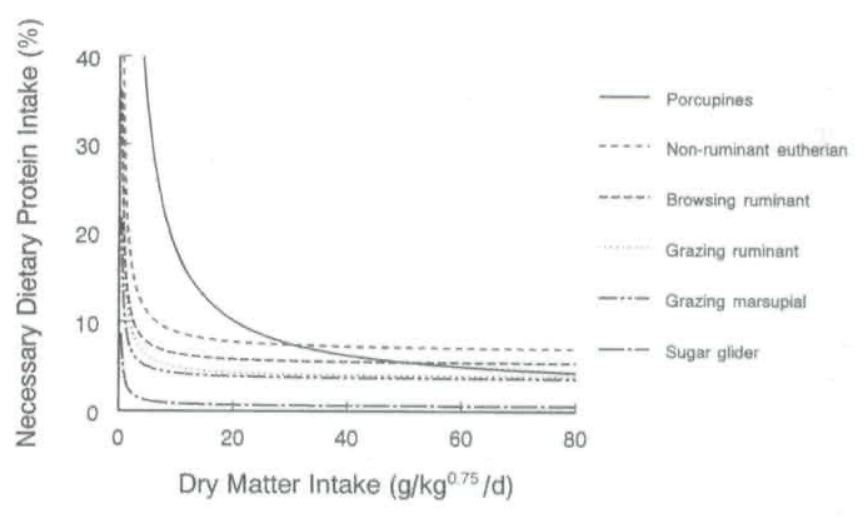

Figure 6. Minimum dietary protein content necessary to meet nitrogen balance for captive North American porcupines (current study) as compared with different groups of mammals (Robbins 1993). 


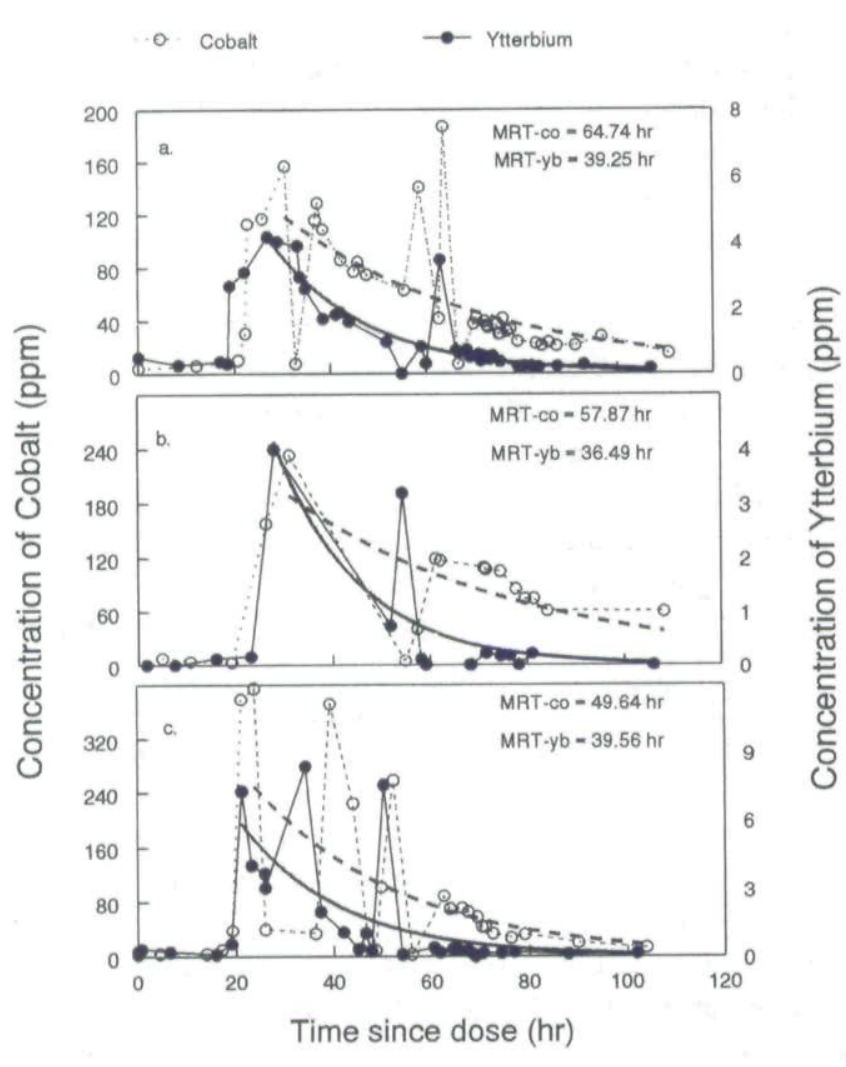

Figure 7. Excretion curves for liquid (cobalt) and particulate (ytterbium) markers fed to three captive North American porcupines $(a-c)$ consuming Pacific willow leaves. Bold broken (cobalt) and solid (ytterbium) lines depict exponential functions fit to the downward portion of the marker concentration data for each animal.

capable of efficiently extracting energy and protein from fibrous, tannin-containing forages. Like other temperate herbivores, porcupines likely have the ability to decrease their metabolic rate when deprived of abundant, digestible forage in winter (Irving and Krog 1954; Irving et al. 1955; Dodge 1967), thus increasing their ability to survive on low-quality foods seasonally. Porcupines are widespread in North America, ranging from desert-shrub (Reynolds 1957) to tundra (Murie 1926), and have the potential to cause significant damage to economically valuable timber resources by stripping cambium and girdling trees (Krefting et al. 1962; Witmer and Pipas 1998). Additional work may further elucidate the physiological mechanisms by which these generalist herbivores can extract energy from high-fiber forages like tree cambium.

\section{Acknowledgments}

We thank B. Davitt for the use of his lab and his time. We also thank L. Klimas, S. Jenkins, M. Cleland, M. Stevens, R. Applegrin, and G. Radamaker for caring for animals, harvesting forages, and preparing for trials. This project was funded in part by the USDA/Animal and Plant Health Inspection Service.

\section{Literature Cited}

Alexander R.M. 1993. The relative merits of foregut and hindgut fermentation. J Zool Soc Lond 231:391-401.

Annison G. and M. Choct. 1991. Relationship between the levels of soluble non-starch polysaccharides and the apparent metabolizable energy of wheats assayed in broiler chickens. J Agric Food Chem 39:1252-1256.

Batzli G.O. and I.D. Hume. 1994. Foraging and digestion in herbivores. Pp. 313-314 in D.J. Chivers and P. Langer, eds. The Digestive System in Mammals: Food, Form and Function. Cambridge University Press, Cambridge.

Björnhag G. 1987. Comparative aspects of digestion in the hindgut of mammals: the colonic separation mechanism (CSM). Dtsch Tieraerztl Wochenschr 94:33-36.

Black H.C. 1992. Silvicultural approaches to animal damage management in Pacific Northwest forests. Gen. Tech. Rep. PNW-GTR-287. USDA Forest Service, Pacific Northwest Research Station, Portland, Oreg.

Brandt C.S. and E.J. Thacker. 1958. A concept of rate of food passage through the gastrointestinal tract. J Anim Sci 17: 218-223.

Choct M. and G. Annison. 1990. Anti-nutritive activity of wheat Pentosans in broiler diets. Br Poult Sci 31:811-821.

Conklin N.L. and E.S. Dierenfeld. 1994. Digestibility and passage of standard zoo diet fed to greater mouse deer (Tragulus napu). Malay Nat J 48:41-51.

Conklin-Brittain N.L. and E.S. Dierenfeld. 1996. Small ruminants: digestive capacity differences among four species weighing less than $20 \mathrm{~kg}$. Zoo Biol 15:481-490.

Cork S.J. 1994. Digestive constraints on dietary scope in small and moderately-small mammals: how much do we really understand? Pp. 370-390 in D. J. Chivers and P. Langer, eds. The Digestive System in Mammals: Food, Form, and Function. Cambridge University Press, Cambridge.

Dodge W.E. 1967. The Biology and Life History of the Porcupine (Erethizon dorsatum) in Western Massachusetts. $\mathrm{PhD}$ diss. University of Massachusetts, Amherst.

Feng P., C.W. Hunt, G.T. Pritchard, and S.M. Parish. 1995. Effects of barley variety and dietary barley content on digestive function in beef steers fed grass hay-based diets. J Anim Sci 73:3476-3480.

Fleck D.C. and D.F. Tomback. 1996. Tannin and protein in the diet of a food hoarding granivore, the western scrub-jay. Condor 98:474-482.

Fournier F. and D.W. Thomas. 1997. Nitrogen and energy requirements of the North American porcupine, Erethizon dorsatum. Physiol Zool 70:615-620.

Goering H.K. and P.J. Van Soest. 1970. Forage analyses (ap- 
paratus, reagents, procedures and some applications). USDA Agric Handb 379:1-20.

Gray D.H. and J.R. Vogt. 1974. Neutron activation analysis of stable heavy metals as multiple markers in nutritional monitoring. J Agric Food Chem 22:144-146.

Hagerman A.E. and C.T. Robbins. 1992. Specificity of tanninbinding salivary proteins relative to diet selection by mammals. Can J Zool 71:628-633.

Hume I.D. 1982. Digestive Physiology and Nutrition of Marsupials. Cambridge University Press, Cambridge.

Irving L. and H. Krog. 1954. The body temperature of arctic and subarctic birds and mammals. J Appl Physiol 6:667-680.

Irving L., H. Krog, and M. Monson. 1955. The metabolism of some Alaskan animals in winter and summer. Physiol Zool 28:173-185.

Johnson J.L. and R.H. McBee. 1967. The porcupine cecal fermentation. J Nutr 91:540-546.

Koenig W. 1991. The effects of tannins and lipids on digestion of acorns by acorn woodpeckers. Auk 108:79-88.

Krefting L.W., J.H. Stoeckeler, B.J. Bradle, and W.D. Fitzwater. 1962. Porcupine-timber relationships in the lake states. J For 60:325-330.

Mader T.L., Teeter R.G., and Horn G.W. 1984. Comparison of forage labeling techniques for conducting passage rate studies. J Anim Sci 58:208-212.

McArthur C. and G.D. Sanson. 1991. Effects of tannins on digestion in the common ringtail possum (Pseudocheirus peregrinus), a specialized marsupial folivore. J Zool (Lond) 225 : 233-251.

Murie O.J. 1926. The porcupine in northern Alaska. J Mammal 7:109-113.

Oprin C.G. and K.N. Joblin. 1988. The rumen anaerobic fungi. Pp. 21-76 in P.N. Hobson, ed. The Rumen Microbial Ecosystem. Elsevier Applied Science, New York.

Parra P. 1978. Comparison of foregut and hindgut fermentation in herbivores. Pp. 205-229 in G. Montgomery, ed. The Ecology of Arboreal Folivores. Smithsonian Institution, Washington, D.C.

Reynolds H.G. 1957. Porcupine behavior in the desert-shrub type of Arizona. J Mammal 38:418-419.

Robbins C.T. 1993. Wildlife Feeding and Nutrition. Academic Press, San Diego, Calif.
Robbins C.T., T.A. Hanley, A.E. Hagerman, O. Hjeljord, D.L. Baker, C.C. Schwartz, and W.W. Mautz. 1987a. Role of tannins in defending plants against ruminants: reduction in protein availability. Ecology 68:98-107.

Robbins C.T., S. Mole, A.E. Hagerman, and T.A. Hanley. $1987 b$. Role of tannins in defending plants against ruminants: reduction in dry matter digestion? Ecology 68:1606-1615.

Roze U. 1984. Winter foraging by individual porcupines. Can J Zool 62:2425-2428.

- 1989. The North American Porcupine. Smithsonian Institution, Washington, D.C.

Sakaguchi E., H. Itoh, S. Uchida, and T. Horigome. 1987. Comparison of fiber digestion and digesta retention time between rabbits, guinea pigs, rats and hamsters. Br J Nutr 58:149-158.

SAS Institute. 1985. SAS User's Guide: Statistics. SAS Institute, Cary, N.C.

Schutte J.B., J.D. Jong, E.J. van Weerden, and S. Tamminga. 1992. Nutritional implications of L-arabinose in pigs. $\mathrm{Br}$ Nutr 68:195-207.

Snyder M.A. and Y.B. Linhart. 1997. Porcupine feeding patterns: selectivity by a generalist herbivore? Can J Zool 75: 2107-2111.

Tenneson C. and L.W. Oring. 1985. Winter food preferences of porcupines. J Wildl Manag 49:28-33.

Theodorou M.K., S.E. Lowe, and A.P.J. Trinci. 1988. The fermentative characteristics of anaerobic rumen fungi. Biosystems 21:371-376.

Uden P., P.E. Colucci, and P.J. Van Soest. 1980. Investigation of chromium, cerium and cobalt as markers in digesta: rate of passage studies. J Sci Food Agric 31:625-632.

Van Soest P.J. 1982. Nutritional Ecology of the Ruminant. O\&B Books, Corvallis, Oreg.

Vispo C. and I.D. Hume. 1995. The digestive tract and digestive function in the North American porcupine and beaver. Can J Zool 73:967-974.

Wenninger P.S. and L.A. Shipley. 2000. Harvesting, rumination, digestion, and passage of fruit and leaf diets by a small ruminant, the blue duiker. Oecologia 123:466-474.

Witmer G.W. and M.J. Pipas. 1998. Porcupine damage and repellent research in the interior Pacific Northwest. Proc Vertebr Pest Conf 18:203-207. 
Copyright of Physiological \& Biochemical Zoology is the property of University of Chicago Press and its content may not be copied or emailed to multiple sites or posted to a listserv without the copyright holder's express written permission. However, users may print, download, or email articles for individual use. 